Пархомець Микола, Уніят Людмила. Поняття, сутність та еволюція розвитку агропромислового бізнесу в підприємствах. Економічний дискурс. 2019. Випуск 3. С. 7-14.

DOI:

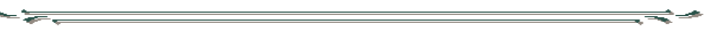

УДК 338.436:338.439:338.439.01

JEL Classification B50, B10

\title{
Пархомець Микола
}

д.е.н., професор, професор кафедри економіки біоресурсів та природокористування

\section{Уніят Людмила}

д.ф., к.е.н., доцент, докторант кафедри обліку та економіко-правового забезпечення агропромислового бізнесу

Тернопільський національний економічний університет

м. Тернопіль, Україна

E-mail: luda@uniyat.in.ua

\section{ПОНЯТТЯ, СУТНІСТЬ ТА ЕВОЛЮЦІЯ РОЗВИТКУ АГРОПРОМИСЛОВОГО БІЗНЕСУ В ПІДПРИЕМСТВАХ}

\section{Анотація}

Bcmyn. Агропромисловий бізнес відіграє важливу роль для економічного розвитку усіх суб'єктів підпиємницької діяльності регіональних і національного АПК. Його головна функція постійно спрямовується на реалізацію виробленої продукції, отримання обігових коштів, необхідних для належного відтворення підприємницької діяльності, оплати праці працівників, сплати зобов'язань та отримання прибутку. Водночас на практиці рівень ефективності агропромислового бізнесу підприємств регіонів має суттєві відхилення від середніх показників країни, а деякі агропромислові підприємства збиткові. При цьому в літературних джерелах висловлюється думка та проводиться аналіз діяльності підприємств агробізнесу, що потребує обгрунтування щодо повної назви. Все це обумовлює об'єктивну необхідність дослідження теоретичних організаційноекономічних аспектів економічної та соціальної ефективності функціонування підприємств агропромислового бізнесу, що й обумовило вибір теми дослідження.

методи. В дослідженні застосовувалися такі методи: монографрічний - для детального вивчення явищ, процесів; історичний - для вивчення еволюції розвитку агропромислового бізнесу; абстрактно-логічний - для опрацювання літературних джерел, теоретичних положень, формування висновків; теоретичного узагальнення та ін.

Результати. Розкрито поняття, сутність та еволюцію агробізнесу, дано його авторське тлумачення, обгрунтовано об'єктивну необхідність змінити діючу назву «агробізнес» на нову - «агропромисловий бізнес», виділено рівні агропромислового бізнесу (I - підприємства, II - країна, III - міжнародний масштаб) і основні аспекти підвищення його ефрективності та конкурентоспроможності.

Перспективи. Підвищення ефективності агропромислового бізнесу має здійснюватися шляхом активного 
використання внутрішніх і зовнішніх чинників функціонування підприємств АПК.

Ключові слова. агропромисловий бізнес, підприємниитво, сільське господарство, переробна промисловість, економічні відносини, економічна і соціальна ефективність, витрати, доходи, прибуток, інтеграція, конкурентоспроможність.

\section{Вступ.}

Агропромисловий бізнес $є$ головною ланкою агропромислової економіки у кожному регіоні. Ринкові умови ведення бізнесу обумовлюють підприємців підвищувати ефективність виробництва шляхом використання інноваційних технологій, ефективних форм менеджменту, раціонального використання наявних ресурсів, поліпшення якості та конкурентоспроможності реалізованої продукції.

\section{Аналіз останніх досліджень та публікацій.}

Теоретичні, методичні й практичні аспекти агробізнесу та шляхи його поліпшення висвітлені у працях: зарубіжних вчених - Дж. Девіса і П. Голдберга [11]; Дж. Сакса [12] та ін. [9; 10; 13]; українських вчених - І. Абрамовича [1]; Г. Андрусенко і В. Мартьянова [2]; І. Брюховецького [3]; Ю. Губені [4]; В. Семенова; І. Сіваченко, В. Федоряка [7; 8] та ін. Ці наукові розробки дуже важливі, проте у теоретико-методичному аспекті залишаються недостатньо вивченими проблеми ефективного фрункціонування агропромислового бізнесу, потребують уточнення поняття «агробізнес» в сучасних умовах, перспективи сталого розвитку та конкурентоспроможності економіки АПК.

\section{Мета.}

Метою даного дослідження є поглиблення теоретико-методичних основ понятійного апарату та розкриття змістовної сутності поняття агропромислового бізнесу в сучасних умовах; обірунтування напрямів підвищення ефективності бізнесової діяльності та її конкурентоспроможності у складових АПК.

\section{Методологія дослідження.}

Теоретичною і методичною основою дослідження стали праці зарубіжних і вітчизняних учених економістів, нормативно-правові документи з питань розвитку агропромислового бізнесу.

\section{Результати.}

Опрацювання літературних джерел $[1 ; 2 ; 3 ; 4 ; 7 ; 10 ; 11 ; 12 ; 13]$ показує, що етимологія терміну «агробізнес» $є$ досить простою, підґрунтям його $€$ терміни аграрний і бізнес. Термін «аграрний» запозичений від німецької мови в другій половині XIXст. (нім. agrar - аграрний, землеробський). Щодо терміну «бізнес» (англ. business - справа, підприємництво) - це ініціативна економічна діяльність, здійснювана за рахунок власних або позикових коштів на свій ризик і під свою відповідальність, яка головними цілями ставить отримання прибутку і розвиток власної справи. Отже, з визначення зрозуміло, що бізнес може мати різні напрями (враховуючи всю різноманітність галузей національних економік). Звідси термін «агробізнес» означає один із напрямів ведення бізнесу, а саме в аграрному секторі економіки.

Поняття аграрного бізнесу, як свідчить література [10], полягає в наступному: «агробізнес це соціальний процес, що створює складну структуру багатьох сутностей, незалежних один від одного, а діяльність учасників агробізнесу проникає і доповнює один одного».

Аграрний бізнес - це особлива підсистема економічних відносин, що склалася в аграрному секторі розвинених країн внаслідок злиття аграрного, промислового і торгового капіталів у процесі поглиблення інтеграційних зв'язків між сільським господарством та промисловістю (вертикальної інтеграції) [1].

Літературні джерела $[10 ; 11 ; 12 ; 13]$ засвідчують що на початковому етапі термін 
«агробізнес» в економічній науці вивчався як поняття «підприємництво», визначення якому дав в кінці XVII - на початку XVIII ст. англійський учений Р. Кантільон. Джерелом підприємницької діяльності він вважав землю і працю. Відомі економісти того часу: французький Дж.Б. Сей; англійські А. Сміт, Д. Рікардо надавали вагомого значення саме основним факторам виробництва, додавши до перших двох (земля і праця) третій потужний фактор - капітал. Організаційноекономічні, соціальні та управлінські аспекти розвитку на селі здійснювали потужний вплив і на наукову діяльність учених того часу.

Формування і розвиток агробізнесу зумовлені переходом сільського господарства до машинної стадії виробництва в умовах науково-технічної революції. Остання значно поглибила і розширила економічні й технологічні зв'язки сільського господарства з іншими галузями, прискорила проникнення промислового капіталу в аграрну сферу, що активізувало формування агробізнесу, який став потужним сектором національних економік багатьох країн світу.

Ідея комплексного підходу до вивчення проблем виробництва сировини та її переробки, розподілу і використання сільськогосподарської продукції та продовольства була озвучена в 1955 р. Дж. Х. Девісом (США). У книзі «Поняття агробізнесу» він визначив агробізнес як суму всіх операцій 3 виробництва і розподілу послуг у галузі постачання сільського господарства, виробничих операцій на фермах; зі зберігання, переробки і розподілу сільськогосподарської сировини і предметів споживання [11]. Виходячи з викладеного вище, агробізнес $€$ відтворювальним комплексом галузей і сфер економіки, державних законодавчих і виконавчих установ, які функціонують в єдності й забезпечують виробництво, переробку і збут продукції на основі сільськогосподарської сировини.

Варто зазначити, що більшість вітчизняних і зарубіжних авторів вважають, що агробізнес охоплює всі складові продовольчо-сировинного підкомплексу, однак характеризується зовсім іншим типом економічних взаємовідносин. Саме на важливості нових економічних відносин в агробізнесі акцентує увагу відомий англійський економіст Дж. Сакс, вказуючи, що саме вони (відносини нового типу) визначають суть агробізнесу. Він у 1963 р. опублікував книгу з питань агробізнесу, в якій подав таке визначення: «В даний час існують тісні взаємини між сільським господарством, промисловістю і тими галузями, які переробляють і реалізують сільськогосподарські продукти» [12].

Концепція розвитку агробізнесу започаткована у 50-х роках XX століття американськими вченими-економістами: Дж. Девісом і П. Голдбергом, які розробили ряд міжгалузевих потоків товарів і послуг між національною економікою та окремими складовими агробізнесу. Саме ці вчені створили теорію агробізнесу, яка мала стати способом перемоги над структурною кризою сільського господарства США шляхом необхідності інтеграції фермерів з компаніями, що постачали засоби виробництва, або кінцеву харчову продукцію. Дж. Девіс і П. Голдберг видали першу книгу («Концепція агробізнесу» 1957 р.), в якій було наведено поняття цієї економічної категорії: «Агробізнес означає загальну суму всіх операцій з виробництва та розподілу виробничих товарів для сільського господарства; виробничі операції на фермі; зберігання, переробку і розподіл сільськогосподарської продукції і товарів» [11].

У 1966 році в США видано книгу - «Агробізнес Середнього Заходу: його вплив на економіку країни і міжнародну торгівлю», в якій висвітлено складові агробізнесу: «Сільське господарство в 2-й половині XX ст. швидкими темпами стає взаємопов'язаним з промисловістю. Початкова концепція сільського господарства як виробництва на землі стала поступатися іншій, де сільське господарство $€$ сектором всієї економіки. За такої концепції сільське господарство виходить далеко за межі виробництва продовольства і волокна. Тепер воно включає виробництво, переробку, виготовлення предметів для сільського господарства, торгівлі, використання і споживання.

Цікавим є бачення агробізнесу російськими ученими-економістами [9, с. 72]. Вони: по-перше, виділяють макросередовище агробізнесу, яке представляє сфери діяльності бізнесу - економічні, правові, політичні, соціально-культурні, технологічні, ффізичні чи географічні умови діяльності; подруге, - мікросередовище агробізнесу, яке тісно пов'язане з інституційною системою. Воно представляє органічно поєднану модель взаємодії шести основних функцій бізнесу із зовнішніми 
блоками, а саме: ведення фінансів і обліку - з блоком «ринок грошей, банки, інвестори»; управління кадрами - з ринком робочої сили; матеріально-технічне забезпечення - з ринком сировини, добрив, насіння, машин, енергетичних ресурсів; маркетингу - з діяльністю інститутів розподілу, агентів 3 маркетингу, реклами. Ці підсистеми забезпечують життєдіяльність п'ятої функції - виробничої. Організацію і координацію оптимальної діяльності забезпечує шоста функція - фуннцція менеджменту.

Варто зазначити, що концепція «агробізнесу» розвинутих країн побудована на трисферійній моделі агропромислового комплексу. І сфера - фондоутворювальні виробництва, II сфера сільське господарство, III сфрера - переробка сільськогосподарської сировини, зберігання, транспортування і збут готової продукції. Там у вартості кінцевого продукту АПК найбільшу частку займають складові III сфрери, що свідчить про високий рівень переробки сировини аграрного сектора і забезпечення повного збалансування всіх ссрер АПК.

Таким чином, поняття «агробізнес», по суті, охоплює всі фуннкції, які включає термін «агропромисловий комплекс», проте характеризується зовсім іншим типом економічних взаємовідносин. Новизна економічних відносин в агробізнесі полягає у зміщенні акцентів 3 виробництва і виробничих відносин із сільського господарства та його економіки на цілий «продуктовий ланцюг» та маркетинг [2; 3; 4].

Подібні визначення поняття «агробізнесу» дають вітчизняні вчені: В.Ф. Семенов, І.Ю. Сіваченко, В.П. Федоряк та ін., які вважають, що агробізнес - це форма підприємницької діяльності у сфері виробництва засобів виробництва для аграрного сектора, у сільськогосподарському виробництві, у сфері переробки і реалізації продукції, агросервісного обслуговування виробників. Крім того, автори стверджують, що до аграрного бізнесу залучається все населення, коли розраховує витрати на продукти харчування [7, с. 14].

Сіваченко І.Ю. виділяє також різні рівні функціонування агробізнесу: перший рівень агробізнес у фермерських господарствах, кооперативах, агропромислових об'єднаннях; другий рівень - агробізнес у масштабі національної економіки країни; третій рівень - агробізнес у міжнародному масштабі. На практиці, як стверджує автор, усі три рівні агробізнесу взаємопов'язані [8, с. 10]. Міжнародна система бізнесу, за визначенням автора, являє собою багатогалузевий та багатофункціональний глобальний комплекс, в якому поєднуються виробництво, зберігання, транспортування та реалізація продовольчої продукції у світовому масштабі. Економічні відносини в цьому комплексі формуються на основі міжнародного поділу праці та глобалізації регіональних продовольчих ринків.

Аналіз досліджень зарубіжних і вітчизняних вчених щодо поняття агробізнесу дає змогу стверджувати, що агробізнес, по суті, - це діяльність, направлена на отримання максимального прибутку за умови раціонального використання ресурсів від сільського господарства.

Таким чином, усі сучасні визначення учених щодо поняття агробізнесу підкреслюють, що:

- структурно агробізнес - це сукупність суб'єктів підприємницької діяльності, які діють в аграрному секторі економіки країни. Сюди входить підприємницька діяльність у виробництві засобів виробництва для сільського господарства; власне сільськогосподарське виробництво; зберігання, транспортування і промислова переробка сільськогосподарської продукції, торгівля як сировиною, так і переробленою продукцією. До агробізнесу також входять усі види діяльності з обслуговування сільського господарства (агросервіс, ринкова інфраструктура, використання альтернативних джерел енергіï);

- функціонально агробізнес - це новий тип економічних відносин між суб'єктами аграрного ринку, що характеризуються взаємовигідною співпрацею з врахуванням економічних інтересів усіх його учасників.

Ми вважаємо, що аграрні підприємства (II сфрера АПК) тісно співпрацюють з промисловими підприємствами, які, з одного боку, виробляють матеріально-технічні засоби виробництва, комбікорми, мінеральні добрива, ветеринарні препарати, енергетичні ресурси (I сфера АПК), а 3 
іншого - переробної промисловості (III сфрера АПК) та промисловими підприємствами, що обслуговують виробничу і ринкову інфраструктури. Все це $є$ підставою вважати, що в Україні в ринковому середовищі функціонують не аграрні відносини, а агропромислові, що обумовлює об'єктивну необхідність змінити діючу назву агробізнес на сучасну, нову - «агропромисловий бізнес».

В зв'язку з цим, авторське тлумачення поняття буде таким: «агропромисловий бізнес - це об'єднання усіх економічних відносин між складовими АПК, споживачами та державно-ринковими інституціями щодо раціонального використання земельних, матеріально-технічних, трудових, інформаційних та природних ресурсів на основі запровадження інноваційних техніко-технологічних засобів, цифрової економіки з метою сталого і конкурентоспроможного розвитку економіки АПК».

Систему економічних відносин між суб'єктами агропромислового бізнесу наведено на рисунку 1. Як видно із рисунка, усі учасники агропромислового бізнесу тісно пов'язані економічним інтересом, успіх будь-якого з них є неможливим без успішного функціонування всієї системи.

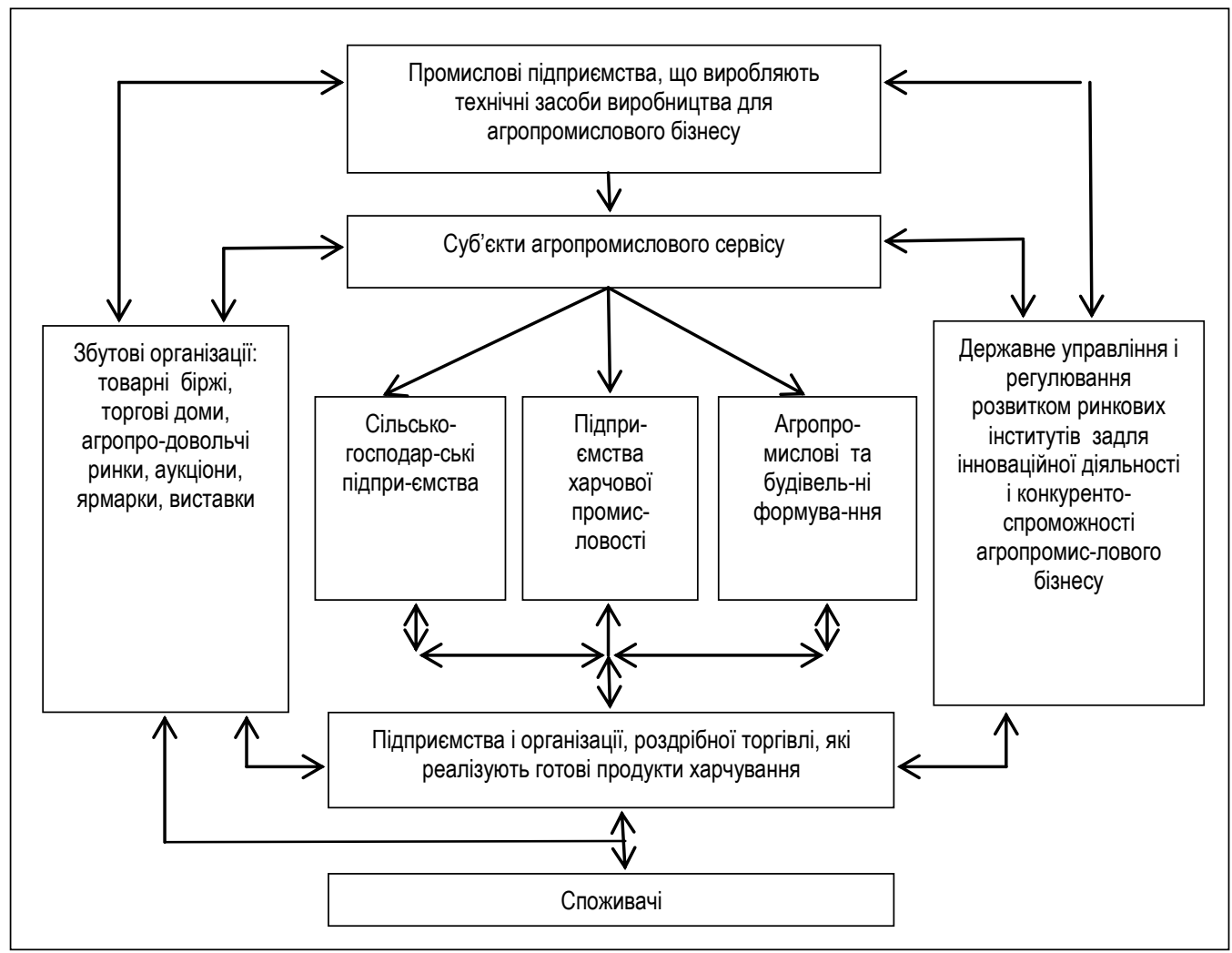

Рис. 1. Схема економічних взаємовідносин в агропромисловому бізнесі*

*Джерело: виконано на основі [1; 5, с. 11; 8]

Усі підприємства агропромислового бізнесу особливо тісно пов'язані із сільськогосподарськими виробниками, оскільки саме сільське господарство задає основні параметри діяльності, з одного боку, галузям з виробництва засобів виробництва, а з іншого галузям з переробки сільськогосподарської продукції, а також суб'єктам інфраструктури аграрного ринку. Тому ефективне та високопродуктивне сільське господарство за агропромисловою бізнесовою схемою організації базується на якісному технічному, фінансовому, маркетинговому та 
науковому забезпеченні. Управління і регулювання інноваційного розвитку агропромислового бізнесу в Україні здійснюють державні структури. Саме завдяки агропромисловому бізнесу сільське господарство економічно розвинутих країн досягло значного прогресу.

Вирішальне значення у формуванні нового структурно завершеного продовольчого підкомплексу за агропромисловою бізнесовою схемою має агропромислова інтеграція. Агропромислова інтеграція передбачає поглиблення технологічних, економічних, організаційних та інших зв'язків між сільськогосподарськими і промисловими підприємствами та розвиток різних агропромислових формувань, які забезпечують раціональне і високоефективне використання всього виробничого потенціалу.

Основними мотивами створення інтегрованих агропромислових підприємств $є$ концентрація капіталу з метою:

- встановлення стабільних виробничо-господарських зв'язків між підприємствами технологічного ланцюга;

- зниження витрат на одиницю продукції за рахунок збільшення масштабів виробництва i підвищення конкурентоспроможності продукції;

- створення умов для диверсифікації виробництва і можливості маневрування ресурсами. [1; $3 ; 4 ; 5 ; 6 ; 8 ; 9 ; 10]$.

У розвинутих країнах використовують два основні види інтеграції: вертикальну інтеграцію і контрактацію. Вертикальна інтеграція - це комбінування двох або декількох стадій виробництва, переробки і збуту аграрної продукції в межах єдиної власності.

Контрактна форма агропромислової інтеграції передбачає укладання сільськогосподарськими підприємствами (фермерами) з промисловими, торговельними компаніями та кооперативами відповідних угод на переробку і збут продукції. Типи контрактів можуть бути різноманітними залежно від характеру продукту, місця знаходження виробника, матеріальних і фінансових можливостей сторін угоди.

Розрізняють дві основні категорії контрактів: збутові і виробничі. Збутові стосуються лише умов реалізації продукції, в них обумовлюють тип, сорт, якість продукції, що постачається, ціну й умови поставки. Виробничі контракти регламентують умови виробництва. Вони укладаються до початку виробничого процесу і жорстко обумовлюють зобов'язання сторін. Як правило, за умовами виробничого контракту, контрагент постачає виробнику засоби виробництва та матеріали (комбікорми для худоби і птиці, насіння, саджанці, добрива тощо), надає кредит, консультаційні послуги. Обов'язком виробника (фермера) є виконання виробничих операцій.

Переваги контрактації для фірми-постачальника полягають у тому, що вона має стабільне надходження продукції у необхідні терміни, а також має можливість контролю за якістю. Сільгоспвиробник у свою чергу має гарантований ринок збуту продукції за завчасно обумовленою ціною та можливість користуватися кредитом [ $5 ; 8 ; 9]$.

Варто зазначити, що упродовж останнього десятиріччя український агропромисловий бізнес активно трансформувався у спільні підприємства 3 іноземними інвестиціями, інтегровані формування (агрохолдинги, компанії, кластери та інші агропромислові підприємства).

Подальший розвиток агропромислового бізнесу показав значну економічну перевагу тих підприємств, що об'єднують сільськогосподарське виробництво сировини, її зберігання, переробку і торгівлю кінцевою продукцією, тобто зародження агропромислової інтеграції, яка залучає до праці значну кількість населення.

\section{Висновки і перспективи.}

Таким чином, досвід підприємницької діяльності в агропромисловому бізнесі дозволяє виділити різні рівні його функціонування: перший рівень - агропромисловий бізнес у сільськогосподарських підприємствах, кооперативах, агропромислових об'єднаннях, фірмах; другий рівень - агропромисловий бізнес в масштабі національної економіки країни; третій рівень - 
агропромисловий бізнес в міжнародному масштабі. На практиці всі три рівні агропромислового бізнесу взаємопов'язані.

у сучасному світі сформувалася міжнародна система агропромислового бізнесу, яка представляє багатогалузевий та багатофункціональний глобальний комплекс, в якому поєднуються виробництво, зберігання, транспортування та реалізація продовольчої продукції у світовому масштабі. Економічні відносини в цьому комплексі формуються на основі міжнародного поділу праці та глобалізації регіональних продовольчих ринків, посилення міжнародної конкурентоспроможності продукції.

Перспективним напрямком подальшого дослідження $€$ об'єктивна необхідність запровадження інноваційних, ресурсозберігаючих технологій виробництва, зберігання, маркетингу та доведення кінцевої продукції до споживача, а також підвищення ефективного, сталого ведення агропромислового бізнесу.

\section{Список використаних джерел}

1. Абрамович І.А. Теоретичні основи та форми прояву аграрного бізнесу. Ефективна економіка. 2011. № 12. URL : http: //www. economy .nayka.com.ua/? op=1 \&z=907. (дата звернення : 25.06.2019).

2. Андрусенко Г.О., Мартьянов В.П. та ін. Організація агробізнесу і підприємництва: навч. посібн. ; за ред. В.П. Мартьянова: Харків. державний аграрн. Універс. Ім. В.В. Докучаєва. Харків. 1998. 280 с.

3. Брюховецький І. М. Основи підприємницької діяльності та агробізнесу: навч. посібник. Суми: Вид-во «Козацький вал», 2001. 474с. 2002. $256 \mathrm{c}$.

4. Губені Ю.Е. Основи підприємництва та агробізнесу : [навч. посібник]. Львів : Українські технології,

5. Международный агробизнес. Учебное пособие. 4-е изд. перераб. и доп. ; под ред. Ю.Г. Козака. К.: Центр учебной литературы, 2013.- 306с.,с.10

6. Мостовий Г.І. Агробізнес: державне регулювання: Монографія. Харків: Основа, 2002. 300 с.

7. Семенов В.Ф., Сіваченко І.Ю., Федоряк В.П. Загальний курс агробізнесу: Навч. посібник ; за ред. В.Ф. Семенова, І.Ю. Сіваченка. К.: Т-во «Знання» - КОО, 2000. 301 с.

8. Сіваченко І.Ю. Міжнародний агробізнес: Навчальний посібник. К.: ЦУЛ, 2003. 208 с.

9. Формирование межгосударстенных интегрированных объединений: методология и практика ; за ред. Л.И. Абалкина, А.С. Заси, А.З. Зельднера и др. М. 2001. 274 с.

10. Agrobiznes - Encyklopedia Zarządzania URL : http: // https://mfiles.pl/pl/index.php/Agrobiznes. (дата звернення : 25.06.2019).

11. Davis J.H. and Goldberg P.A. A concept of agribusiness. Boston. Mass.: Harvard Uniw, 1957.

12. Sykes G. Poultry A. Modern Agribusiness. London: Crosby Lockwood and Son, 1963.

13. Carlson G.. Zilberman D., Miranowski J. Agricultural and environmental Resource Economics. New York; Oxford: Oxford University Press, 1993. P. 441-491.

Статтю отримано: 16.07.2019 / Рецензування 23.08.2019 / Прийнято до друку: 20.09.2019

\section{Mykola Parkhomets}

Dr.Sc. (in Economics), Professor

Department of Economics, Bioresources and Environmental Management

\section{Liudmyla Uniiat}

Ph.D. (in Economics), Associate Professor, Doctoral Student

Department of Accounting and Economics - Legal Providing of Agricultural Business

Ternopil National Economic University

Ternopil, Ukraine

E-mail: luda@uniyat.in.ua

\section{THE CONCEPT, ESSENCE AND EVOLUTION OF AGRO- INDUSTRIAL BUSINESS DEVELOPMENT IN ENTERPRISES}




\section{Abstract}

Introduction. Agro-industrial business plays an important role for the economic development of all business entities of regional and national agro-industrial business. Its main function is constantly focused on the sale of manufactured products, receipt of working capital, necessary for the reproduction of entrepreneurial activity, remuneration of employees, payment of debts and profit receiving. At the same time, in practice, the level of efficiency of agro-industrial business of enterprises in the regions has significant deviations from the national average, and some agro-industrial business enterprises are unprofitable. At the same time, literature sources express an opinion and analyze the activity of agribusiness enterprises, which does not correspond to the full name - "agro-industrial business". All this determines the objective necessity of researching theoretical organizational and economic aspects of economic and social efficiency of of agro-industrial business enterprises functioning, which led to the choice of the research topic.

Methods. The following methods are used in the study: monographic for detailed study of phenomens, processes; historical for the study of the evolution of agribusiness development; abstract and logical for processing of literary sources, theoretical positions, formation of conclusions; theoretical generalization, etc.

Results. The concept, essence and evolution of agribusiness are revealed, its author's interpretation is given, the objective necessity to change the existing name "agribusiness" to new - "agro-industrial business" is substantiated, the levels of agro-industrial business (I - enterprises, II - country, III - international scale) are highlighted and the main aspects of improving its efficiency and competitiveness are determined.

Discussion. Improving the efficiency of agro-industrial business should be achieved through active use of internal and external factors of functioning of agro-industrial enterprises.

Keywords. Agro-industrial business, entrepreneurship, agriculture, manufacturing, economic relations, economic and social efficiency, costs, revenues, profit, integration, competitiveness.

\section{References}

1. Abramovych, I.A. (2011). Teoretychni osnovy ta formy proiavu ahrarnoho biznesu [Theoretical foundations and forms of agrarian business demonstrate]. Elektronne naukove fakhove vydannia "Efektyvna ekonomika» Dnipropetrovskyi derzhavnyi ahrarno-ekonomichnyi universytet [Electronic Scientific Professional Edition "Effective Economics" Dnipropetrovsk State Agrarian and Economic University], 12. Retrieved from http: //www. economy .nayka.com.ua/? op=1 \&z=907 ].

2. Martianov, V.P. (Ed.). (1998). Orhanizatsiia ahrobiznesu i pidpryiemnytstva: navch. posibn [Organization of agribusiness and entrepreneurship: training. manual]. Kharkiv: Kharkiv. derzhavnyi ahrarn. Univers. Im. V.V. Dokuchaieva.

3. Briukhovetskyi, I.M. (2001). Osnovy pidpryiemnytskoi diialnosti ta ahrobiznesu: navch. posibnyk [Fundamentals of business and agribusiness: study. manual]. Sumy: Vyd-vo «Kozatskyi val».

4. Hubeni, Yu.E. (2002). Osnovy pidpryiemnytstva ta ahrobiznesu : navch. posibnyk [Fundamentals of entrepreneurship and agribusiness: teaching. manual]. Lviv : Ukrainski tekhnolohii.

5. Kozak, Yu.G. (Ed.). (2013). Mezhdunarodnyiy agrobiznes. Uchebnoe posobie. 4-e izd. pererab. i dop. [International agribusiness. Tutorial. 4th ed. recycling. and ext ]. Kyiv: Tsentr uchebnoy literatury.

6. Mostovyi, H.I. (2002). Ahrobiznes: derzhavne rehuliuvannia: Monohrafiia [Agribusiness: State Regulation: Monograph]. Kharkiv: Osnova.

7. Semenov, V.F., \& Sivachenko, I.lu. (Eds.). Zahalnyi kurs ahrobiznesu: Navch. posibnyk [General Agribusiness Course: Educ. manual]. Kyiv: T-vo «Znannia».

8. Sivachenko, I.lu. (2003). Mizhnarodnyi ahrobiznes: Navchalnyi posibnyk [International Agribusiness: A Textbook]. Kyiv: TsUL.

9. Abalkin, L.I., Zasi, A.S., \& Zeldner, A.Z. (Eds.). (2001). Formirovanie mezhgosudarstennyih integrirovannyih ob'edineniy: metodologiya i praktika [Formation of interstate integrated associations: methodology and practice]. Moscow.

10. Agrobiznes - Encyklopedia Zarządzania. mfiles.pl. Retrieved from https://mfiles.pl/pl/index.php/Agrobiznes.

11. Davis, J.H., \& Goldberg, P.A. (1957). A concept of agribusiness. Boston. Mass.: Harvard Uniw.

12. Sykes, G., \& Poultry, A. (1963). Modern Agribusiness. London: Crosby Lockwood and Son.

13. Carlson, G., Zilberman, D., \& Miranowski, J.(1993). Agricultural and environmental Resource Economics. New York; Oxford: Oxford University Press.

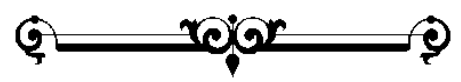

